\title{
The Effect of Green Accounting Implementation on Improving the Environmental Performance of Mining and Energy Companies in Indonesia
}

\author{
${\text { Wahyuni'; }{ }^{1} \text { Inten } \text { Meutia }^{2} \text {; Syamsurijal }}^{3}$ \\ ${ }^{1,2}$ Accounting Department, Faculty of Economics, Sriwijaya University \\ ${ }^{3}$ Economic Science Department, Faculty of Economics, Sriwijaya University \\ Jln. Srijaya Negara Bukit Besar, Palembang 30139, Indonesia \\ ${ }^{1}$ wahyuni.tanjung@gmail.com; ${ }^{2}$ inten26@yahoo.com; ${ }^{3}$ syamsurijalkadir@gmail.com
}

Received: $6^{\text {th }}$ July 2019/ Revised: $5^{\text {th }}$ August 2019/ Accepted: $12^{\text {th }}$ August 2019

How to Cite: Wahyuni, Meutia, I., \& Syamsurijal. (2019). The Effect of Green Accounting Implementation on Improving the Environmental Performance of Mining and Energy Companies in Indonesia. Binus Business Review, 10(2), 131-137. https://doi.org/10.21512/bbr.v10i2.5767

\begin{abstract}
The research explored implementation of green accounting that was taken from the green accounting concept containing quantitative and qualitative information reported by the company. The observation period of this research was three years from 2014 to 2016. The object of this research was the mining and energy companies registered in the Global Reporting Initiative (GRI) database in Indonesia. The data used were secondary data obtained from sustainability reporting with the GRI-G4 report type. Data analysis was using panel data regression with a random effect model approach. The results show that the implementation of green accounting in the form of recycled materials, renewable energy, and green cost allocation has a positive and significant effect on improving environmental performance. Conversely, Corporate Social Responsibility (CSR) fund allocations do not affect environmental performance.
\end{abstract}

Keywords: green accounting, environmental performance, mining and energy companies

\section{INTRODUCTION}

Social and environmental issues become an interesting issue until now. This issue has been widely discussed globally and become the topic of concern for the business world. Over the past few decades, there have been requests from the Indonesian Accounting Association and accounting regulatory authorities. It is to immediately reform the principles, conceptual frameworks, and conservative accounting standards that underlie the accounting practices of corporate entities. This is because so far, the practice is considered to be environmentally friendly and causes a serious ecological crisis (Lako, 2017).

A company in practice is required to preserve the environment by carrying out a development that can balance the economic, social, and environmental aspects (Tu \& Huang, 2015). The company is expected to participate in environmental preservation efforts. This is better known as sustainable development or Planet, People, Profit (3P) (Hussain, Halim, \& Bhuiyan, 2016).

Current industry practices that are caring and environmentally friendly are realized through the application of eco-efficiency in management practices or green accounting in accounting practices. Green accounting applied in corporate accounting practices aims to overcome conservative accounting weaknesses. In addition, the application of green accounting is expected to respond to the needs of corporate entities in recognizing and measuring values, recording, summarizing, reporting and disclosing financial, social and environmental accounting information in an integrated manner (Lako, 2017).

In relation to legitimacy theory, companies need to emphasize social norms and values (Deegan, 2002). 
In addition, the concept of legitimacy also shows the existence of a social contract which the company is responsible for the demands of the community and environment. The concept of legitimacy is manifested in the form of the implementation of green accounting in the company. This is expected to trigger a positive development of the industry through the increased sales followed by increased profits, the sustainability of the company's business, and the selling value of the industry in the eyes of investors (Megwai, Njie, \& Richards, 2016).

In Indonesia, the government has encouraged industries to implement green industry practices through the application of green accounting. One form of government efforts is to give awards to industries that carry out green industry practices. Unfortunately, the application of green accounting in developing countries including Indonesia is still not optimal. Zulhaimi (2015) and Marota (2017) showed that there were still a few companies that implemented green accounting in their environmental performance reports. This was caused by limitations and the lack of legal sanctions in a country (Masud, Bae, \& Kim, 2017).

Furthermore, complete and accurate environmental information will produce good environmental performance (Deswanto \& Siregar, 2018). The results of Khoirina (2016) and Khoiruman and Haryanto (2017) explained that disclosure of environmental costs to management had a positive effect on environmental performance. The results of similar studies were also found related to the application of green accounting to improving environmental performance (Hendratno, 2016).

Some of the studies show that the concept of environmental performance is an abstraction of externalities. Externalities are described as the effects felt by someone caused by the actions of others (Mattmann, Logar, \& Brouwer, 2016). When it is connected with a company, externalities are the effects felt by the community or the environment. The company's operational activities cause it. The perceived effect is minimized through the implementation of green accounting. With the cost of externalities, companies are required to pay for securities from externalities arising from their corporate activities. The costs of this externality can be felt in the future for the community, the environment, and the company itself. In the future, it can also affect the company's environmental performance.

Latan, Chiappetta Jabbour, Lopes de Sousa Jabbour, Wamba, and Shahbaz (2018) described that companies with excellent environmental performance tended to disclose information that was strong, verifiable, and difficult to replicate. Meanwhile, Lisi (2015) showed that there was a positive influence between environmental costs and improved environmental performance. Mastromonaco (2015) and Zhou, Delmas, and Kohli (2017) explained that the measurement of environmental performance was carried out with the Toxic Release Inventory (TRI) to calculate the waste produced by the company. In addition to positive research, there are also some contradictory studies. Qiu, Shaukat, and Tharyan (2016) and Nazari, Hrazdil, and Mahmoudian (2017) showed that there was a negative or insignificant effect between disclosure of environmental information on performance. Furthermore, González-Rodríguez, Díaz-Fernández, and Simonetti (2015) explained that there were differences in the perception of Corporate Social Responsibility (CSR) and the cultural environment, which made the research results insignificant.

The difference in the results of these studies is a research gap that the researchers want to examine. This study seeks to prove the effect of implementing green accounting on improving environmental performance in mining and energy companies in Indonesia. In this study, the implementation of green accounting entities is taken from the concept of green accounting itself. This concept contains quantitative and qualitative information that must be reported by an entity. This information will be mutually integrated and needed in economic and non-economic decision making. Integrated information will provide benefits for the company in the future.

The independent variable in this study is the implementation of green accounting, which is reflected in the form of the recycled materials, renewable energy, the allocation of green costs, and the allocation of CSR funds. The results of green cost funding and CSR funds have been disclosed in the company's sustainability report. The dependent variable is environmental performance. The renewal of this research is in the form of a comprehensive measurement environmental performance. Environmental performance is measured using the environmental impact dimension with the Toxic Releases Index (TRI) indicator. It calculates the total of Bahan Berbahaya dan Beracun (B3 -hazardous and toxic materials) waste that has a direct impact on the environment around the object of research.

The results of this study are expected to assist mining and energy companies in optimizing the implementation of green accounting. Another benefit of implementing green accounting is that it can create a green industry. It is environmentally friendly and does not damage the ecology. This also relates to the company's sustainable development.

In this research, four hypotheses will be used as seen in Figure 1. Those are:

$\mathrm{H}_{1}$ : Recycled material (RM) has positive and significant effect an on improving environmental performance (EP).

$\mathrm{H}_{2}$ : Renewable energy (RE) has positive and significant effect on improving environmental performance (EP).

$\mathrm{H}_{3}$ : Green cost allocation (GC) has positive and significant effect on improving environmental performance (EP). 
$\mathrm{H}_{4}$ : Corporate Social Responsibility (CSR) fund allocations have positive and significant effect on improving environmental performance (EP).

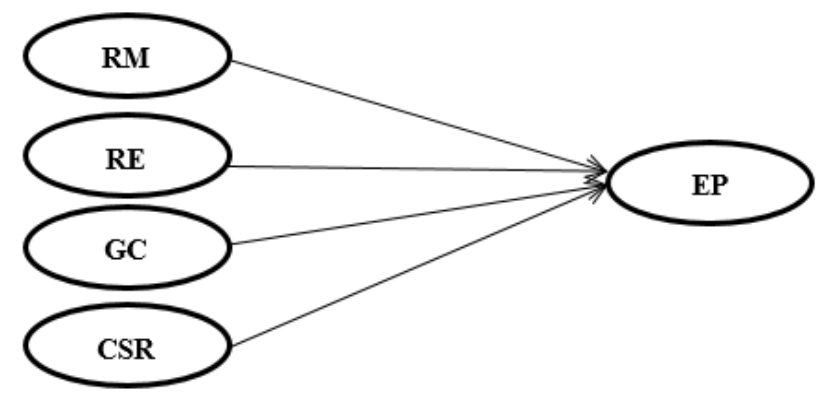

Figure 1 Research Hypotheses

\section{METHODS}

Mining and energy companies in Indonesia are the object of this study. The selection of the object is considered the companies which are large industries concern on the environment and contributing greatly to the changes in the environmental and social structure. Ching, Gerab, and Toste (2014) explained that the sampling for large companies used purposive sampling techniques. Purposive sampling is a sampling technique with criteria that can be seen in Table 1. The population in this study are mining and energy companies in Indonesia contained in the Global Reporting Initiative (GRI) database. Mining companies that are sampled include PT Aneka Tambang Tbk, PT Bukit Asam Tbk, PT Indo Tambangraya Megah Tbk, PT Kaltim Prima Coal, PT Petrosea Tbk, PT Timah Tbk, PT Semen Indonesia Tbk, and PT Vale Indonesia Tbk. Meanwhile, the energy companies used are PT Elnusa Tbk, PT Indika Energy Tbk, PT Perusahaan Gas Negara Tbk, PT Perusahaan Listrik Negara Tbk, PT AKR Corporindo Tbk, PT Medco Energi Internasional Tbk, PT Badak Liquified Natural Gas, PT Power Indonesia, PT Pertamina Tbk, PT Pertamina EP, PT Pertamina Geothermal Energy, and Star Energy (Kakap) Ltd.

At present, reports with GRI-G4 type are used by companies to develop a sustainable framework consisting of economic, social, and environmental reports. This standard contains elements that must be reported by the entity in the sustainability report. Mining and energy companies are also chosen because these two companies are two large companies dominating the GRI database. In addition, most companies have also implemented the implementation of green accounting and reported sustainability consistently every year.

The year of research observation is three years, from 2014 to 2016 . The selection of the year is because the new GRI-G4 report type is released in mid-2013. Thus, the company has begun implementing it since 2014 and beyond. This research limits the type of report used in the form of the latest GRI-G4 type. The number of mining companies and energy found in the GRI database from 2014 to 2016 are 25 companies. By using the purposive sampling method, the result is 60 observations.

This research uses quantitative data. Quantitative data is a type of data that can be assessed, measured, and calculated directly in the form of information and expressed by numbers or numerical forms. The data source is secondary data. Secondary data are generally in the form of notes, evidence, historical reports arranged in an archive/documentary data. Secondary data from this research are reports on the sustainability of mining and energy companies with GRI-G4 report types and annual reports for 2014 to 2016.

In addition, this study uses descriptive analysis to describe statistical data, such as minimum and maximum value, mean, and standard deviation. Statistical testing is presented by using tables of descriptive statistics. It describes the research variables. Hypothesis testing uses regression analysis by utilizing the Eviews 10 software. The panel data regression model used is as follows:

EPit $=\alpha+\beta 1$ RMit $=\beta 2$ REit $+\beta 3$ GCit $+\beta 4 C S R i t+$ eit

Where:

EPit : Environmental performance

$\alpha \quad$ : Constanta

$\beta 1-\beta 4$ : Regression coefficient

i : Entity for $\mathrm{i}$

$\mathrm{t}$ : Period for $\mathrm{i}$

RM : Use of recycled materials (Ton)

RE : Use of Renewable Energy (Giga Joule)

GC : Allocation of green cost (Rupiah)

CSR : CSR Funding Allocation (Rupiah)

e : Error

To see the presence or absence of autocorrelation in this study, the researchers conduct the DurbinWatson (DW) test. The selection of panel data regression models is through three approaches. Those are common effect model, fixed effect model, and random effect model. To determine the appropriate model approach, the researchers use Chow and Hausman tests. Hypothesis testing is done by t-test and f-test.

\section{RESULTS AND DISCUSSIONS}

The research sample is chosen by purposive sampling method. Table 1 is a sample derivation. Based on the criteria of the sample, it is known that the samples meeting the requirements are 20 mining and energy companies found in the GRI database from 2014 to 2016. The total observations made as research samples are 60 observations with three years of observation. The sustainability report used in this 
study is a report with type GRI-G4, which contains economic, social, and environmental information for each company.

Table 1 Sample Derivation

\begin{tabular}{lc}
\hline Criteria of the Sample & $\begin{array}{l}\text { Number of } \\
\text { Firms }\end{array}$ \\
\hline $\begin{array}{l}\text { Mining companies in Indonesia are registered in } \\
\text { the GRI database for } 2014 \text { to } 2016\end{array}$ & 9 \\
$\begin{array}{l}\text { Energy companies in Indonesia are registered in } \\
\text { the GRI database for } 2014 \text { to } 2016\end{array}$ & 16 \\
$\begin{array}{l}\text { Mining and energy companies do not have } \\
\text { complete data related to the variables used } \\
\text { Companies do not issue GRI-G4-based }\end{array}$ & $(2)$ \\
sustainability reporting for 2014 to 2016 & $(3)$ \\
$\begin{array}{l}\text { Number of research samples } \\
\text { Number of years of observation }\end{array}$ & 20 \\
\hline Total observations & $\mathbf{6 0}$ \\
\hline
\end{tabular}

(Source: Author's Calculation)

Table 2 shows the descriptive statistics for each research variable. The results of descriptive statistical analysis of environmental performance variable using the dimensions of environmental impact with TRI show a minimum value of 0,100000 obtained by PT Pertamina Tbk in 2014. The mean value is 0,667500 . It shows that the level of the environmental performance of mining and energy companies in Indonesia as measured by the TRI indicator is $66,75 \%$. This value is not optimal enough.

Other independent variables, such as the use of recycled materials, show a minimum value of 0,610000 obtained by PT Aneka Tambang Tbk in 2014. The average value is 0,810500 . It shows that the use of recycled material from mining and energy companies in Indonesia is $81,05 \%$. The value obtained is relatively high showing that the implementation of green accounting in the form of the use of recycled materials has been carried out optimally.
Next, the variable of renewable energy use shows a minimum value of 0,380000 obtained by PT Pertamina Tbk in 2016. The average value is 0,795667 . It implies that the use of renewable energy such as biomass, biofuels, and hydropower of mining and energy companies in Indonesia is $79,56 \%$. The value obtained is relatively high. It means that the implementation of green accounting in the form of the use of renewable energy has been carried out optimally.

The variable of green cost allocation shows the minimum value of 0,360000 obtained by PT Pertamina Tbk in 2014. The average value is 0,73600 . It indicates that the green cost allocation in the form of environmental costs in mining and energy companies in Indonesia is $73,60 \%$. The value obtained is relatively high. It suggests that the implementation of green accounting in the form of green cost allocation has been carried out to the maximum.

The CSR fund allocation variable shows a minimum value of 0,310000 obtained by PT Pertamina EP in 2014. The average value is 0,77850 . The CSR fund allocation in the form of community empowerment costs for mining and energy companies in Indonesia is $77,85 \%$. The value obtained is high. It means that the implementation of green accounting in the form of CSR fund allocation has been carried out maximally.

Furthermore, the most appropriate modeling is used for this study through two tests. Those are Chow test and Hausman test. Chow test and Hausman test are conducted to determine the exact estimation model. The test criteria state that if the chi-square test statistics with probability is $<\alpha=0,05, \mathrm{H}_{0}$ is rejected. It means that the effect in the panel regression estimation model used is the fixed effect model. Conversely, if the probability is $\geq \alpha=0,05, \mathrm{H}_{0}$ is accepted. It suggests that the effect in the panel regression estimation model that matches the data is the random effect model.

The Hausman test results show that the value of the chi-square probability is $0,8644>\alpha=0,05$. It can be concluded that $\mathrm{H}_{0}$ is accepted and $\mathrm{H}_{1}$ is rejected. This shows that the panel regression estimation model used in the study is the random effect model. The results of the calculation are shown in Table 3.

Table 2 Descriptive Statistics

\begin{tabular}{ccccc}
\hline Variable & Minimum & Maximum & Mean & Std.Deviation \\
\hline TRI & 0,100000 & 0,930000 & 0,667500 & 0,186907 \\
PB & 0,610000 & 0,980000 & 0,810500 & 0,098676 \\
PE & 0,380000 & 0,960000 & 0,795667 & 0,126255 \\
GC & 0,360000 & 0,910000 & 0,736000 & 0,144717 \\
CSR & 0,310000 & 0,930000 & 0,778500 & 0,114815 \\
\hline
\end{tabular}

(Source: Data Processed Using Eviews 10) 
Table 3 Hausman Test

\begin{tabular}{lcc}
\hline Test Summary & Chi-Sq Statistic & Prob. \\
\hline Cross-section random & 1,281983 & 0,8644 \\
\hline
\end{tabular}

(Source: Data Processed Using Eviews 10)

Based on the results of the Hausman Test, it is known that the random effect model is an approach model used in this study. Therefore, the panel data regression model equation can be written as follows:

$$
\begin{aligned}
& Y_{i t}=0,6855+0,1523 X 1_{i t}-0,0646 X 2_{i t}+ \\
& 0,2726 X 3_{i t}-0,3273 X 4_{i t}+\varepsilon
\end{aligned}
$$

The equation of the panel data regression model can be explained. First, the constant of 0,6855 indicates that if there is no change in the independent variable, the environmental performance is 0,6855 . Second, the value of the coefficient of $X_{1}$, which is the implementation of green accounting in the form of the use of recycled materials is 0,1523 . It indicates that if the value of the variable increases by 1 score, the value of environmental performance will increase by 0,1523 . Assuming other variables is considered as constant (0).

Third, the variable coefficient of $\mathrm{X}_{2}$, which is the implementation of green accounting in the form of renewable energy use is $-0,0646$. It implies that if the value of the variable increases by 1 score, the value of environmental performance will decrease by $-0,0646$ by assuming other variables as constant (0). Fourth, the value of the $\mathrm{X}_{3}$ variable coefficient, which is the implementation of green accounting in the form of green cost allocation is 0,2726 . It means that if the value of the variable increases by 1 score, the value of environmental performance will increase by 0,2726 by assuming other variables as constant (0). Last, the variable coefficient of $X_{4}$, which is the implementation of green accounting in the form of CSR fund allocation is $-0,3273$. If the value of the variable increases by 1 score, the value of environmental performance will decrease by $-0,3273$. It is by assuming other variables as constant $(0)$.

Furthermore, to detect autocorrelation problems, the DW is carried out. The aim is to test whether in a regression model, there is a correlation between intruder errors or not. The results of the DW test are shown in Table 4.

Table 4 Durbin Watson Test

\begin{tabular}{cc}
\hline Model & Durbin Watson \\
\hline 1 & 1,853898 \\
\hline
\end{tabular}

(Source: Data Processed Using Eviews 10)

Based on Table 4, it is known that DW test model is 1,853898 . The value is in the $\mathrm{dU}-(4-\mathrm{dU})$ criteria. The results suggest that there is no autocorrelation in the regression model used. Next, the hypothesis testing uses f-test and t-test. The feasibility test of the model (f-test) identifies whether the regression model estimated is feasible or not. It shows that the estimated model can be used to explain the effect of independent variables on the dependent variable. The f-test results are explained in Table 5. Based on Table 5, it can be seen that the significance value of $F$ count is 0,018438 $<$ level of error 0,05 . It means that statistically, the model is significant. This shows that the regression model estimated to be feasible is used to explain environmental performance with the TRI indicator.

Table 5 (F-Test)

\begin{tabular}{lc}
\hline & Score \\
\hline F-statistic & 1,994407 \\
Prob. (F-statistic) & 0,018438 \\
\hline
\end{tabular}

(Source: Data Processed Using Eviews 10)

Table 6 Results of the Random Effect Model Estimation

\begin{tabular}{ccccc}
\hline Variable & Coefficient & Std. Error & T-Statistic & Prob. \\
\hline $\mathrm{C}$ & 0,685524 & 0,293820 & 2,333145 & 0,0233 \\
$\mathrm{X}_{1}$ & 0,152338 & 0,302249 & 0,504015 & 0,0163 \\
$\mathrm{X}_{2}$ & $-0,064647$ & 0,244158 & 0,264777 & 0,0022 \\
$\mathrm{X}_{3}$ & 0,272693 & 0,232685 & 1,171940 & 0,0363 \\
$\mathrm{X}_{4}$ & $-0,327348$ & 0,211747 & $-1,54593$ & 0,1279 \\
\hline
\end{tabular}

(Source: Data Processed Using Eviews 10) 
The next hypothesis test is the partial test results (t-test). The results can be seen in Table 6. Partial significance test (t-test) aims to determine whether there is an influence of independent variables on the dependent variable or not. The testing criteria is if the probability is $<\alpha=0,05$, there is a significant influence between recycled materials, renewable energy, the allocation of green costs, and the allocation of CSR funds to improve environmental performance.

Table 6 shows that t-count of $X_{1}$ variable is 0,504015 with a probability level of 0,0163 . It is smaller than the significance level of 0,05 . Thus, it can be concluded that the $\mathrm{H}_{1}$ is accepted. The implementation of green accounting in the form of the use of recycled materials affects environmental performance.

The value of t-count from the $X_{2}$ variable is 0,26477 with a probability level of 0,0022 . It is smaller than the significance level of 0,05 . Thus, it can be said that the $\mathrm{H}_{2}$ is accepted. The implementation of green accounting in the form of renewable energy has an effect on improving environmental performance. Next, the value of t-count from the $\mathrm{X}_{3}$ variable is 1,171940 with a probability level of 0,0363 . It is smaller than the significance level of 0,05 . It can be concluded that $\mathrm{H}_{3}$ is accepted. The implementation of green accounting in the form of green cost allocation has an effect on improving environmental performance. Then, the value of t-count from the $X_{4}$ variable is $-1,545938$ with a probability level of 0,1279 . It is greater than the significance level of 0,05 . Thus, $\mathrm{H}_{4}$ is rejected. The implementation of green accounting in the form of CSR fund allocation does not affect the improvement of environmental performance.

Based on the results of hypothesis testing conducted, it is known that the implementations of recycled materials, renewable energy, and green cost allocation have a positive effect on improving environmental performance mining and energy companies in Indonesia. This result is in accordance with Marota (2017), Hendratno (2016), and Khoirina (2016). This result is also consistent with the legitimacy theory. The rationale of this theory explains that a company will continue to be sustainable if the community realizes that it operates for a system of values that are the same as the existing value system of society. Based on the theory, a concept is found regarding the importance of implementing green accounting for companies because it reflects the responsibility that the company has made towards the environment. In addition, improving the company's environmental performance can provide signals and information to investors regarding the company's substantial prospects in the future. This is consistent with signaling theory.

Different results are shown from hypothesis testing for the CSR fund allocation variables. The results of t-test indicate that there is no influence between the allocation of CSR funds and improving environmental performance in mining and energy companies in Indonesia. This study is consistent with González-Rodríguez, Díaz-Fernández, and Simonetti
(2015) and Nazari, Hrazdil, and Mahmoudian (2017). Furthermore, CSR dimensions referred to the triple bottom line approach (financial, social, and environmental) must be considered. The results show that human values influence human perceptions of CSR. This knowledge can be very useful to companies to achieve vital social goals such as a good reputation or prestige (Angelia \& Suryaningsih, 2015). Based on this explanation, it is known that CSR funds allocated by companies do not have a direct effect on environmental performance. Social and community activities dominate the allocation of CSR funds from mining and energy companies.

\section{CONCLUSIONS}

The results of the implementation of green accounting on improving environmental performance by using environmental impact dimensions with indicators of TRI in mining and energy companies in Indonesia show two results. First, the implementation of green accounting in the form of recycled raw materials, renewable energy, and green cost allocation has a significant positive effect on improving environmental performance. However, CSR fund allocations have not been proven to be influential in improving the company's environmental performance.

Based on the legitimacy theory, a concept is found regarding the importance of implementing green accounting for the company. It reflects the responsibility that has been carried out by the company towards its environmental and social aspects. Maximum implementation of green accounting is expected to improve environmental performance. This performance improvement is what the entity wants to achieve because it has a positive influence on the sustainability of the company.

In today's era, companies are required to develop green industry concepts and green corporations as an effort to realize sustainable development and overcome the ecological crisis and social crisis. Therefore, accounting is prepared to internalize various externalities as a consequence of industrial processes. Therefore, the green accounting concept emerges. Furthermore, green accounting will consider the economic and non-economic values of objects, integrated economic or financial, social and environmental transactions, and account for such information in an integrated manner.

This research contributes to a guideline for investors to invest by considering the company's business sustainability. A good company is a company that discloses all financial, social, and environmental information in its corporate sustainability report. This shows that the company gives signals to targeted investors. In addition, the practical implication of this research is that the government must make clear and transparent regulations regarding the practice of implementing green accounting for companies. It is especially for companies based on natural resources, such as mining and energy companies. 
The limitation of this study is the availability of GRI-G4 report data in the GRI database starting in 2014 and 2016. Only the $\mathrm{X}_{4}$ variable has no significant results. This result is caused by unstable CSR funds that the company has every year. This can be seen from the company's sustainability report. Besides that, the period of observation also affects the results of the study. Thus, future researchers need to add the observation period to get optimal results. It is important to consider further research on TRI in other companies that are more diverse.

\section{REFERENCES}

Angelia, D., \& Suryaningsih, R. (2015). The effect of environmental performance and corporate social responsibility disclosure towards financial performance (Case study to manufacture, infrastructure, and service companies that listed at Indonesia Stock Exchange). Procedia-Social and Behavioral Sciences, 211(November), 348-355. https://doi.org/10.1016/j.sbspro.2015.11.045

Ching, H. Y., Gerab, F., \& Toste, T. H. (2014). Scoring sustainability reports using GRI indicators: A study based on ISE and FTSE4Good Price indexes. Journal of Management Research, 6(3), 29-48. https://doi. org/10.5296/jmr.v6i3.5333

Deegan, C. (2002). Introduction: The legitimising effect of social and environmental disclosures-A theoretical foundation. Accounting, Auditing \& Accountability Journal, 15(3), 282-311. https://doi. org/10.1108/09513570210435852

Deswanto, R. B., \& Siregar, S. V. (2018). The associations between environmental disclosures with financial performance, environmental performance, and firm value. Social Responsibility Journal, 14(1), 180193. https://doi.org/10.1108/SRJ-01-2017-0005

González-Rodríguez, M. R., Díaz-Fernández, M. C., \& Simonetti, B. (2015). The social, economic and environmental dimensions of Corporate Social Responsibility: The role played by consumers and potential entrepreneurs. International Business Review, 24(5), 836-848. https://doi.org/10.1016/j. ibusrev.2015.03.002

Hendratno, S. P. (2016). Corporate point of view in green accounting. Binus Business Review, 7(3), 247-253. https://doi.org/10.21512/bbr.v7i3.1499

Hussain, M. D., Halim, M. S. B. A, \& Bhuiyan, A. B. (2016). Environmental accounting and sustainable development: An empirical review. International Journal of Business and Technopreneurship, 6(2), 335-350.

Khoirina, M. M. (2016). Analysis of green accounting to support Corporate Social Responsibility (Case study: Semen Gresik Hospital). AKRUAL: Jurnal Akuntansi, 8(1), 1-10.

Khoiruman, M., \& Haryanto, A. T. (2017). Green purchasing behavior analysis of government policy about paid plastic bags. Indonesian Journal of Sustainability Accounting and Management, 1(1), 31-39. https:// doi.org/10.28992/ijsam.v1i1.25
Lako, A. (2017). Ecological crisis and urgency of green accounting. Majalah Akuntan Indonesia, (JulyAugust), 1-11. DOI: 10.13140/RG.2.2.21872.15361

Latan, H., Chiappetta Jabbour, C. J., Lopes de Sousa Jabbour, A. B., Wamba, S. F., \& Shahbaz, M. (2018). Effects of environmental strategy, environmental uncertainty and top management's commitment on corporate environmental performance: The role of environmental management accounting. Journal of Cleaner Production, 180(April), 297-306. https:// doi.org/10.1016/j.jclepro.2018.01.106

Lisi, I. E. (2015). Translating environmental motivations into performance: The role of environmental performance measurement systems. Management Accounting Research, 29(December), 27-44. https:// doi.org/10.1016/j.mar.2015.06.001

Marota, R. (2017). Green concepts and material flow cost accounting application for company sustainability. Indonesian Journal of Business and Entrepreneurship (IJBE), 3(1), 43-51. https://doi. org/10.17358/ijbe.3.1.43

Mastromonaco, R. (2015). Do environmental right-to-know laws affect markets? Capitalization of information in the toxic release inventory. Journal of Environmental Economics and Management, 71(May), 54-70. https://doi.org/10.1016/j.jeem.2015.02.004

Masud, M. A. K., Bae, S. M., \& Kim, J. D. (2017). Analysis of environmental accounting and reporting practices of listed banking companies in Bangladesh. Sustainability, 9(10), 1-19. https://doi.org/10.3390/ su9101717

Mattmann, M., Logar, I., \& Brouwer, R. (2016). Hydropower externalities: A meta-analysis. Energy Economics, 57(June), 66-77. https://doi.org/10.1016/j. eneco.2016.04.016

Megwai, G., Njie, N. I., \& Richards, T. (2016). Exploring green economy strategies and policies in developing countries. International Journal of Green Economics, 10(3-4), 338-357. https://doi. org/10.1504/IJGE.2016.081905

Nazari, J. A., Hrazdil, K., \& Mahmoudian, F. (2017). Assessing social and environmental performance through narrative complexity in CSR reports. Journal of Contemporary Accounting \& Economics, 13(2), 166-178. https://doi.org/10.1016/j.jcae.2017.05.002

Qiu, Y., Shaukat, A., \& Tharyan, R. (2016). Environmental and social disclosures: Link with corporate financial performance. British Accounting Review, 48(1), 102116. https://doi.org/10.1016/j.bar.2014.10.007

Tu, J. C., \& Huang, H. S. (2015). Analysis on the relationship between green accounting and green design for enterprises. Sustainability, 7(5), 6264-6277. https:// doi.org/10.3390/su7056264

Zhou, P., Delmas, M. A., \& Kohli, A. (2017). Constructing meaningful environmental indices: A nonparametric frontier approach. Journal of Environmental Economics and Management, 85(September), 2134. https://doi.org/10.1016/j.jeem.2017.04.003

Zulhaimi, H. (2015). Pengaruh penerapan green accounting terhadap kinerja perusahaan. Jurnal Riset Akuntansi dan Keuangan, 3(1), 603-616. 